\title{
Distribution of congenital malformations at birth in a tertiary care hospital in North-Western Rajasthan
}

\author{
Ritu $\operatorname{Vyas}^{1}$, Suniti Verma ${ }^{2}$, V. K. Malu ${ }^{3}$
}

\begin{abstract}
${ }^{1}$ Department of Obstetrics and Gynaecology, Govt. Medical College, Kota, Rajasthan, India
${ }^{2}$ Department of Obstetrics and Gynaecology, SP Medical College, Bikaner, Rajasthan, India

${ }^{3}$ Department of Anaesthesia, Kota Heart Institute, Kota, Rajasthan, India
\end{abstract}

Received: 19 September 2016

Revised: 20 October 2016

Accepted: 18 October 2016

\section{*Correspondence:}

Dr. Ritu Vyas,

E-mail: drritumalu@gmail.com

Copyright: (C) the author(s), publisher and licensee Medip Academy. This is an open-access article distributed under the terms of the Creative Commons Attribution Non-Commercial License, which permits unrestricted non-commercial use, distribution, and reproduction in any medium, provided the original work is properly cited.

\begin{abstract}
Background: A significant number of neonates are born with congenital anomalies. It is one of the leading cause of neonatal/infant mortality worldwide. The morbidity and disability experienced by surviving children and their parents also has major public health impact. This study was planned to find incidence of such birth defects and their system wise distribution.

Methods: This was an observational prospective study during one year period from Jan 2012 to Dec 2012 in Dept. of Obstetrics and Gynecology, PBM Medical college Hospital, Bikaner (Rajasthan).

Results: Out of total 13,614 consecutive live/still births, 167 neonates were found to have congenital malformations. The overall incidence being $1.23 \%$ (12.3/1000 births). Commonest (53.3\%) anomalies were of CNS followed by other systems.

Conclusions: This study was an effort to find frequency and distribution pattern of congenital malformations at birth in a tertiary care centre of North -Western Rajasthan. CNS was found to be the commonest site of such defects followed by cleft lip and palate and others.
\end{abstract}

Keywords: Neural Tube Defect, Congenital Telipes Equinovarus

\section{INTRODUCTION}

Congenital malformations are morphological defects that occur in the prenatal period as a result of genetic mutation, chromosomal abnormalities and adverse intrauterine environment. These are present at birth and clinically manifest at any time in life. ${ }^{1}$

Congenital malformations have been known and recognized for centuries. It is a problem for research because of high frequency of their occurrence and devastating effect they may have on the individual and family. Congenital anomalies account for $8-15 \%$ of perinatal deaths and $13-16 \%$ of neonatal deaths in India. ${ }^{2,3}$

Congenital anomalies cause a significant proportion of infant mortality and morbidity and health care expenditure. As a consequence, it is essential to have basic epidemiological information of these anomalies. Congenital anomaly rates have also been used for primary health services planning.

This study was carried out to find incidence and distribution of the neonates born with these defects. 


\section{METHODS}

The present study was an observational study carried out during the period from Jan 2012 to Dec 2012 amongst the patients admitted in Dept of Obstetrics and Gynecology, PBM Hospital, Bikaner.

This hospital serves both urban and rural population and is a tertiary referral hospital of North-Western Rajasthan. All congenital anomalous babies (Live and Still) born here during the study period, either detected before birth by USG of mother or detected at birth were included in this study.

\section{RESULTS}

Table 1 shows distribution of anomalies in various systems.

Out of total 167 neonates born with anomalies, 82 were still births and 85 were live births. 150 neonates had single system defects and remaining 17 were found to be having multiple system anomalies.

Table 1: Distribution of cases according to system.

\begin{tabular}{|lll|}
\hline System & No. & $\%$ \\
\hline CNS & 89 & 53.3 \\
\hline GIT & 22 & 13.2 \\
\hline Multiple & 17 & 10.2 \\
\hline Musculoskeletal & 15 & 9.0 \\
\hline Miscellaneous & 11 & 6.6 \\
\hline Urogenital & 8 & 4.8 \\
\hline Respiratory & 3 & 1.8 \\
\hline CVS & 2 & 1.2 \\
\hline Total & 167 & 100 \\
\hline
\end{tabular}

Out of total 13,614 births, 431 were still born and out of these 82 were found to have birth defects - $18.3 \%$ incidence. This is much higher than 85 live born neonates having birth defects out of a total of 13,183 live births incidence of $0.64 \%$.

Table 2: Pattern of distribution of anomalies according to various systems.

\begin{tabular}{|c|c|c|c|}
\hline System & Anomalies & No. & $\%$ \\
\hline \multirow{5}{*}{ CNS } & Anencephaly & 42 & 47.2 \\
\hline & Corpus Callosum Agenesis & 1 & 1.1 \\
\hline & Hydrocephalus & 34 & 38.2 \\
\hline & Meningoencephalocele & 1 & 1.1 \\
\hline & Meningocele & 11 & 12.3 \\
\hline CVS & CHD & 2 & 100.0 \\
\hline \multirow{3}{*}{ GIT } & Cleft Lip and Palate & 16 & 72.7 \\
\hline & Gastroschisis & 2 & 9.1 \\
\hline & Omphalocele & 4 & 18.2 \\
\hline Respiratory & Diaphragmatic Hernia & 3 & 100 \\
\hline \multirow{5}{*}{ Urogenital } & Ambiguous Genitalia & 2 & 25.0 \\
\hline & B/L Hydronephrosis & 1 & 12.5 \\
\hline & Hypospadias & 2 & 25.0 \\
\hline & Polycystic kidney Disease & 2 & 25.0 \\
\hline & Post. Urethral Valve & 1 & 12.5 \\
\hline \multirow{5}{*}{ Musculoskeletal } & CTEV & 9 & 60.0 \\
\hline & Achondroplasia & 1 & 6.7 \\
\hline & Polydactyly & 2 & 13.3 \\
\hline & Sacrococcygeal Teratoma & 1 & 6.7 \\
\hline & Skeletal Dysplasia & 2 & 13.3 \\
\hline \multirow{4}{*}{ Miscellaneous } & Downs Syndrome & 2 & 18.2 \\
\hline & Non Immune Hydrops Fetalis & 7 & 63.6 \\
\hline & Marfans Syndrome & 1 & 9.1 \\
\hline & Pierre Robbins syndrome & 1 & 9.1 \\
\hline
\end{tabular}

In our study, we had 17 cases of Multi system involvement (10.2\%). Most of the major anomalies were associated with minor anomalies of another system (Table 3).
Out of the 85 live born babies 15 expired within 15 minutes of birth. 
Table 3: Distribution of cases according to multiple systems.

\begin{tabular}{|lll|}
\hline Multiple System & No. & $\%$ \\
\hline Absent Radius, Dextrocardia, Polydactyly & 1 & 5.9 \\
\hline $\begin{array}{l}\text { Ambiguous Genitalia, Cleft palate, } \\
\text { Polydactyly }\end{array}$ & 1 & 5.9 \\
\hline Anencephaly, Kyphoscoliosis & 1 & 5.9 \\
\hline B/L CTEV, Gastroschisis, Encephalocele & 1 & 5.9 \\
\hline Cleft lip and Palate Rt Sided Cataract & 1 & 5.9 \\
\hline Cleft lip and Palate, CTEV & 1 & 5.9 \\
\hline Cleft lip and Palate, Skeletal Dysplasia & 1 & 5.9 \\
\hline Depressed Nasal Bridge, Low Set Ears & 1 & 5.9 \\
\hline Holoprosencephaly kyphoscoliosis & 1 & 5.9 \\
\hline Hydrocephalus, Achondroplasia & 1 & 5.9 \\
\hline Microtia with Absent radius & 1 & 5.9 \\
\hline $\begin{array}{l}\text { Meningocele, Hydrocephalus, } \\
\text { Kyphoscoliosis }\end{array}$ & 1 & 5.9 \\
\hline $\begin{array}{l}\text { Mircrognathia, Hypoplastic upper limb, } \\
\text { Skeletal Dysplasia, CTEV }\end{array}$ & 1 & 5.9 \\
\hline $\begin{array}{l}\text { Meningocele, Diaphragmatic Hernia, cleft } \\
\text { palate }\end{array}$ & 1 & 5.9 \\
\hline Polycystic Kidney disease with CHD & 1 & 5.9 \\
\hline $\begin{array}{l}\text { Polydactyly, Ambiguous Genitalia, eye } \\
\text { ball absent }\end{array}$ & 1 & 5.9 \\
\hline Polydactyly, Congenital cataract & 1 & 5.9 \\
\hline Total & 17 & 100 \\
\hline
\end{tabular}

Out of the 70 remaining, $35(50 \%)$ babies were discharged from hospital as stable; 24 babies expired while 6 were operated upon and 5 were transferred to higher centers (Table 4).

Table 4: Distribution of cases according to fetal outcome.

\begin{tabular}{|lll|}
\hline Fetal Outcome & No. & $\%$ \\
\hline Discharged & 35 & 50.0 \\
\hline Expired & 24 & 34.3 \\
\hline Operated & 6 & 8.6 \\
\hline Referred & 5 & 7.1 \\
\hline Total & 70 & 100 \\
\hline
\end{tabular}

\section{DISCUSSION}

Similar other studies around the world revealed incidence of congenital malformation in all births to vary between $3-8 \%$ showing an incidence in live birth of $0.8-5 \%$ and in still births from $5-15 \%$. $^{4-11}$

In most of the studies, CNS malformations were commonest. $^{12-14}$ But in few of the studies, multiple system, CVS, musculoskeletal, G I tract or genitourinary system malformations were found to be the commonest. ${ }^{9,15-20}$

The commonest anomalies in our study were of CNS $(53.3 \%)$ followed by G I system (13.2\%), multiple system involvement (10.2\%), musculoskeletal (9\%), miscellaneous $(6.6 \%)$ uro-genital (4.8), respiratory (1.8\%) and CVS (1.2\%) (Table 2).

The congenital malformations involving the central Nervous system were the most common in the various studies. ${ }^{7,12-14}$

In our study, majority of babies with CNS anomalies were either still born or died within a week and only 6 babies got operated and discharged.

The prognosis for anencephalic fetuses is poor. Most are still born and most that are born alive die within $24 \mathrm{hrs}$ after birth. Ensuring folic acid supplement during preconception period can lower the frequency of these anomalies. Apart from folic acid supplementation, early diagnosis of NTDs and advising early termination of affected pregnancies with lethal anomalies will help to lower occurrence rate of congenital anomalies at birth. ${ }^{21}$

In our study, there were 22 cases who had anomalies of $\mathrm{G}$ I tract (13.2\%) - cleft lip and palate - 16, Gastroschisis- 2, omphalocele - 4 .

In our study, there were 15 cases of musculoskeletal anomalies (9\%) which included CTEV (9), Achondroplasia (1), Polydactyly (2), Sacrococcygeol teratoma (1) and skeletal dysplasia (2). But these anomalies were mostly minor and non-fatal and most of them were diagnosed after birth. Most of babies were referred to orthopedician or paediatric surgeon. Baby with sacrococcygeal teratoma and skeletal dysplasia did not survive.

Malformations of urogenital system are not uncommon; we had 8 cases $(4.85 \%)$ of urogenital anomalies, consisting of ambiguous genitalia (2), bilateral hydronephrosis (1), hypospadias (2), polycystic kidney disease (2) and posterior urethral valve (1). Current ultrasound diagnostic capability allows for the detection of urinary tract anomalies as early as 12-14 weeks of gestation. In our study, 1 case of hydronephrosis was diagnosed before delivery, while 2 cases of ambiguous genitalia, 2 cases of hypospadias 1 case of polycystic kidney disease and 1 case of posterior urethral valve could not be detected by USG and were diagnosed at birth. Both cases of polycystic kidney disease did not survive.

In our study, we had 3 cases of diaphragmatic hernia and 2 cases of congenital heart disease. Only 1 case of diaphragmatic hernia was diagnosed before birth. One case of diaphragmatic hernia was referred to higher centre; 2 cases did not survive.

We came across some of the other anomalies in our study; Non-immune hydrops fetalis (NIHF) (7), Down Syndrome (2), Marfan's Syndrome (1) and Pierre Robbins Syndrome (1). NIHF were diagnosed before 
delivery and were still born while Down's syndrome was diagnosed after birth on the basis of clinical features in babies. Marfan's Syndrome baby was of very low birth weight and did not survive.

Table 4 shows distribution of cases according to fetal outcome. Out of total 85 live born neonates, 24 expired immediately or within a week of admission in NICU.

167 mothers who delivered malformed babies whether major or minor were taken into full confidence and were given the following advice:

(1). Parents were explained the developmental pathology of the defect, so as to assist in the partial acceptance of the child by not branding the whole child a malformed but considering the child otherwise normal except for a localized defect, e.g. Cleft lip and palate which the plastic surgeon could take care of.

(2). Most parents attributed the cause of congenital malformations to exposure to eclipse which has no scientific bearing, misunderstandings were cleared.

(3). Recurrence and risk factors were explained particularly when a baby delivered with multiple congenital malformations.

(4). Parents were explained about the advantage of early antenatal enrollment as prenatal diagnosis can be done in certain disorders was explained to the parents at the time of discharge.

(5). All mothers who delivered or aborted a fetus with neural tube defect were offered supplementation with folic acid $4 \mathrm{mg}$ per day preconceptionally in the next pregnancy.

Funding: No funding sources

Conflict of interest: None declared

Ethical approval: The study was approved by the Institutional Ethics Committee

\section{REFERENCES}

1. Sadler TW. Congenital malformations. Langman's Medical Embryology. $8^{\text {th }}$ ed; 2000:95.

2. Kumar MR, Bhat BV, Oumachigui A. Perinatal mortality trends in a referral hospital. Indian $\mathrm{J}$. Pediatr. 1996;63:357-61.

3. Chaturvedi P, Banerjee KS. Spectrum of congential malformations in the newborns from rural Maharashtra. Indian J Pediatr. 1989;56:501-7.

4. Choudhury AR, Mukherjee M, Sharma A, Talukder G, Ghosh PK. Study of 1,26,266 consecutive births for major congential defects. Indian J Pediatr. 1989;56(4):493-9.

5. Agarwal SS, Singh U, Singh PS, Singh SS, Das V, Sharma A, et al. Prevalence and spectrum of congenital malformations in a prospective study at a teaching hospital. Indian J Med Res. 1991;94:413-9.
6. Desai NA. Congenital anomalies. A prospective study at a teaching hospital. Indian J Pediatr. 1991;94:413-9.

7. Verma M, Chhatwal J, Singh D. Congenital malformations- a retrospective study of 10,000 cases. Indian J Pediatr. 1991;58(2):245-52.

8. Chaturvedi P, Banerjee KS. An epidemiological study of congenital malformations in newborn. Indian J Pediatr. 1993;60(5):645-53.

9. Kumar V, Singh AJ, Marwaha RK. An epidemiological study of congenital malformations in rural children. Indian J Pediatr. 1994;31(8):90914.

10. Kato K, Fujiki K. Incidence of congenital malformations in Tokyo Metropolitan Hospitals, 1979-1993. Brain Dev. 1996;18(3):230-3.

11. Samaha I, Rady M, Nabhan A, Gadallah M. The prevalence of congenital malformations at birth in Ain Shams University Maternity Hospital Cairo, Egypt, 1994. J Egypt Public Health Assoc. 1995;70(5-6):595-608.

12. Grover N. Congenital malformations in Shimla. Indian J Pediatr. 2000;67(4):249-51.

13. Al-Jama F. Congenital malformations in newborns in a teaching hospital in eastern Saudi Arabia. J Obstet Gynaecol. 2001;21(6):595-8.

14. Mahadevan B, Bhat BV. Neural tube defects in Pondicherry. Indian J Pediatr. 2005;72(7):557-9.

15. Mishra OC, Baveja R. Congenital malformations in the newborn-a prospective study. Indian Pediatr. 1989;26(1):32-5.

16. Fida NM, Al-Aama J, Nichols W, Alqahtani M. A prospective study of congenital malformations among live born neonates at University Hospital in Western Saudi Arabia Saudi Med J. 2007;28(9):47784.

17. Bhat BV, Babu L. congenital malformations at birtha-prospective study from South India. Indian J Pediatr. 1998;65(6):873-81.

18. Golalipour MJ, Ahmadpour-Kacho M, Vakili MA. Congenital malformations at a referral hospital in Gorgan, Islamic Republic of Iran. East Mediterr Health J. 2005:11(4):707-15.

19. Ronya R, Gupta D, Ghosh SK. Narang R, Jain KB. Spectrum of congenital surgical malformations in newborns. J Indian Med Assoc. 2002;100(9):565-6.

20. Mosayebi Z, Movahedian AH. Pattern of congenital malformations in consanguineous versus nonconsanguineous marriages in Kashan, Islamic Republic of Iran. East Mediterr Health J. 2007;13(4):868-75.

21. Sarkar B, Bhaduria S, Gupta, Chandra M. Ultrasound evaluation of pregnancies at risk for congenital anomalies. J Obst Gynaec Ind. 1991;40(1):40.

Cite this article as: Vyas R, Verma S, Malu VK. Distribution of congenital malformations at birth in a tertiary care hospital in North-Western Rajasthan. Int J Reprod Contracept Obstet Gynecol 2016;5:4281-4. 